\title{
Level of adipokines and insulin resistance in obese Javanese population
}

\author{
Pramuji Hastuti*, Tasmini, Ahmad Hamim Sadewa, Chornelia DM, Karita D \\ Department of Biochemistry, Faculty of Medicine, Universitas Gadjah Mada, Yogyakarta \\ Indonesia
}

\begin{abstract}
Obesity is a condition involving low-level chronic inflammation as indicated by increased levels of C-reactive protein (CRP), tumor necrosis factor alpha (TNF- $\alpha$ ), interleukin (IL) and other inflammatory markers in the blood. Some endocrine mediators, such as paracrine and autocrine play an important role in regulating the function of adipocytes, especially related to insulin sensitivity. The purpose of this study is to determine the level CRP, TNF- $\alpha$, IL-6, resistin and insulin resistance in the obese Javanese population. This was a preliminary study involving 120 people, consisting of 60 obese subjects and 60 non obese subjects as controls. Lipid profiles, CRP, TNF- $\alpha$, IL-6, resistin levels were determined with ELISA methods, whereas insulin resistance was calculated by HOMA IR index. The study found that the glucose, insulin, CRP levels and HOMA-IR of obese subjects were significantly higher than those non obese subjects $(p<0.05)$. However, the TNF- $\alpha$, IL- 6 and resistin levels were not significantly different between obese and non obese subjects $(p>0.05)$. In conclusion, the CRP levels ad insulin resistance in obese Javanese population were higher compared with those non obese.
\end{abstract}

\section{ABSTRAK}

Obesitas merupakan suatu kondisi yang melibatkan peradangan kronis tingkat rendah seperti ditunjukkan oleh peningkatan kadar protein C-reaktif (CRP), tumor necrosis factor alpha (TNF- $\alpha$ ), interleukin (IL) dan penanda inflamasi lainnya dalam darah. Beberapa mediator endokrin, seperti parakrin dan autokrin berperan penting dalam mengatur fungsi adiposit, terutama yang berkaitan dengan sensitivitas insulin. Tujuan penelitian ini adalah untuk menetapkan kadar CRP, TNF- $\alpha$, IL- 6 , resistin dan resistensi insulin pada populasi Jawa obes. Penelitian ini merupakan studi pendahuluan yang melipatkan 120 subjek, terdiri dari 60 subjek obes 60 tidak obes sebagai kontrol. Profil lipid, kadar CRP, TNF- $\alpha$, IL-6, dan resistin diukur dengan metode ELISA, sedangkan resistensi insulin dihitung dengan indeks IR HOMA. Dari penelitian ini ditemukan bahwa kadar glukosa, insulin, CRP, dan HOMA-IR subjek obes lebih tinggi secara bermakna dibandingkan subjek non obes $(p<0,05)$. Namun demikian kadar TNF- $\alpha$, IL- 6 dan resistin tidak berbeda bermakna antara kelompok subjek obes dan non obes $(p>0,05)$. Dapat disimpulkan, kadar CRP dan resistensi insulin pada populasi Jawa obes lebi tinggi dibandingkan dengan mereka yang tidak obes.

Keywords : obese - insulin resistance - CRP - TNF- $\alpha$, IL-6 - resistin 


\section{INTRODUCTION}

In 2013, Ministry of Health, Republic of Indonesia reported $18.8 \%$ of population in 12 major cities in Indonesia were overweight and $3.7 \%$ of them were obese. ${ }^{1}$ Obesity involves a state of low-level chronic inflammation as indicated by increased levels of C-reactive protein (CRP), tumor necrosis factor-alpha $(\mathrm{TNF}-\alpha)$, interleukin, resistin and other inflammatory markers in the blood. Some endocrine mediators such as, paracrine and autocrine derived from adipose tissue play an important role in regulating the function of adipocytes, especially those related to insulin. Significant complications of obesity, especially insulin resistance include many of the risk factors of type 2 diabetes mellitus (type $2 \mathrm{DM}$ ). ${ }^{2,3}$.

Adipokines (adipocitokines) include TNF- $\alpha$, IL-6, resistin and CRP are secreted primarily in adipose cells in mice and mononuclear cells in humans as a result of inflammation process. Adipokines play an important role in regulating energy, glucose and fat homeostasis and maintain fasting blood glucose levels by modulating hepatic insulin. ${ }^{4}$ Low levels of adipokines are already in circulation, but there are increased levels in people with insulin resistance, type $2 \mathrm{DM}$ and cardiovascular disease. Hypoadiponectinemia increases the risk of coronary artery disease, and shows that adipokine plays a role in metabolic syndromes. ${ }^{5}$ It was reported that the increase of risistin levels not only stimulates the expression but also degrades of low density lipoprotein-cholesterol (LDL-cholesterol) receptors in liver cells. ${ }^{6}$

Resistin is an antagonist of insulin and mediates insulin-signaling pathways playing a role in the pathogenesis of insulin resistance. Excessive resistin expression in adipose tissues of obese people might act to mediate the modulation of insulin sensitivity. ${ }^{7}$ Experiments with exogenous administration of TNF- $\alpha$ in animals induced insulin resistance while decreasing TNF- $\alpha$ improve insulin sensitivity. There is increasing levels of TNF- $\alpha$ in patients with diabetes correlated with Body Mass Index (BMI) and Homeostatic Model Assessment of Insulin Resistance (HOMA-IR). This relationship was stronger in women than men. ${ }^{8}$ Over production of cytokine is correlated with the initial onset of inflammation and is a prognostic indicator of inflammation due to obesity and metabolic syndromes. IL-6 as a mediator of inflammatory, acting as an autocrine regulator of adipocytes may cause the negative effects on metabolic processe. ${ }^{9}$ This was a preliminary study in order to evaluate the levels of adipokines and insulin resistance in obese Javanese people in Yogyakarta Special Region, Indonesia.

\section{MATERIALS AND METHODS}

\section{Subjects}

This was an observational study with a cross sectional design in order to compare the adipokines levels and insulin resistance in obese with non obese Javanese people in Indonesia. One hundred and twenty subjects consisting 60 obese subjects and 60 non obese subjects were involved in this study. Subjects with body mass index (BMI) $>25$ for obese and 18.5 to 23 for non obese with the ages from 18 to years were included in this study. Subjects who taking corticosteroid and antibiotics were excluded from this study. The protocol of this study has been approved by the Medical Health Research Ethics Committee, Faculty of Medicine, Universitas Gadjah Mada, Yogyakarta.

\section{Protocol}

Each subject received written and verbal explanations concerning the background, objectives and benefit of the study before 
signing an informed consent form. After obtaining written informed consent, all subjects were screened through a detailed questionnaires, medical history and physical examination. Age, sex, height, weight, BMI, waist to hip ratio, blood pressure, family history and present medications were recorded for each subject.

Each subject who fulfilled the inclusion and exclusion criteria, blood sample was collected for analysis. Blood glucose level was estimated by glucose oxidase-peroxidase method, cholesterol was estimated by cholesterol oxidase-peroxidase method, high density lipoprotein-cholesterol (HDLcholesterol) was estimated by the glycerol-3phosphate oxidase-peroxidase-N-methyanilin propan-sulphonate sodic method and triglyceride was estimated by GPO-PODESPT method using auto analyzer. Serum CRP, TNF- $\alpha$, IL-6, resistin and insulin levels were measured using ELISA method. The insulin resistance was estimated by the HOMA-IR index calculation as follow : (insulin $(\mu \mathrm{U} /$
$\mathrm{mL}) \times[$ glucose $(\mathrm{mmol} / \mathrm{L}) / 22.5]$. Subjects were considered having insulin resistance if HOMA IR value $>2.0 .^{10}$

\section{Statistical analysis}

Data of obese and non obese groups were presented as mean \pm standard deviation (SD) and analyzed by student $t$ test. The statistical analysis was considered significant if $p$ value $<0.05$.

\section{RESULTS}

One hundred and twenty subjects consisting 60 obese and 60 non obese were involved in this study. The characteristics of subjects are presented in TABLE 1. Significantly higher in the body weight, BMI, waist/hip ratio and diastolic blood pressure between obese and non obese groups were observed in this study $(\mathrm{p}<0.05)$. The higher waist circumference value in the obese group compared to non obese group indicated that they have abdominal obesity.

TABLE 1. Characteristic of subjects (mean \pm SD).

\begin{tabular}{lccc}
\hline Characteristic & Obese & Non obese & $\mathrm{p}$ \\
\hline Gender & & & \\
$\bullet$ Male & 36 & 29 & \\
$\bullet$ Female & 24 & 31 & \\
Age (year) & $21.1 \pm 2.8$ & $20.9 \pm 3.7$ & 0.170 \\
Body weight $(\mathrm{kg})$ & $83.9 \pm 14.6$ & $53.4 \pm 8.1$ & 0.000 \\
Height (m) & $1.627 \pm 0.079$ & $1.607 \pm 0.068$ & 0.147 \\
BMI $\left(\mathrm{kg} / \mathrm{m}^{2}\right)$ & $31.5 \pm 3.5$ & $20.6 \pm 2.3$ & 0.000 \\
Waist circumference (cm) & $96.7 \pm 11.3$ & $72.3 \pm 7.8$ & 0.000 \\
Hip circumference $(\mathrm{cm})$ & $110.7 \pm 8.3$ & $89.3 \pm 6.9$ & 0.000 \\
Waist/hip ratio & $0.872 \pm 0.069$ & $0.812 \pm 0.082$ & 0.000 \\
Systolic blood pressure (mmHg) & $113.8 \pm 10.7$ & $111.9 \pm 10.7$ & 0.333 \\
Diastolic blood pressure (mmHg) & $76.3 \pm 7.5$ & $73.3 \pm 8.7$ & 0.050 \\
\hline
\end{tabular}


TABLE 2 showed lipid profile and HOMA IR value of obese and non obese groups. Significantly higher in the blood glucose and insulin levels as well as HOMA IR value in the obese group compared to non obese group were observed in this study $(\mathrm{p}<0.05)$. Moreover, significantly higher in triglyceride level and significantly lower in HDLcholesterol level in obese group compared to non obese group were also reported $(\mathrm{p}<0.05)$.

TABLE 2. Level blood glucose, insulin, HOMA IR and lipid profile (mean $\pm \mathrm{SD}$ ) in obese and non obese groups

\begin{tabular}{lccc}
\hline Variable & Obese & Non obese & $\mathrm{p}$ \\
\hline Blood glucose $(\mathrm{mg} / \mathrm{dL})$ & $85.4 \pm 29.1$ & $71.6 \pm 19.6$ & 0.003 \\
Insulin $(\mu \mathrm{L} \mathrm{U} / \mathrm{mL})$ & $33.19 \pm 22.00$ & $16.27 \pm 14.61$ & 0.000 \\
HOMA-IR & $3.63 \pm 3.11$ & $1.53 \pm 1.49$ & 0.000 \\
Cholesterol $(\mathrm{mg} / \mathrm{dL})$ & $156.6 \pm 32.2$ & $170.6 \pm 19.6$ & 0.121 \\
Triglyceride $(\mathrm{mg} / \mathrm{dL})$ & $143.4 \pm 26.1$ & $120.0 \pm 22.9$ & 0.000 \\
HDL-cholesterol $(\mathrm{mg} / \mathrm{dL})$ & $35.39 \pm 11.35$ & $54.62 \pm 15.51$ & 0.000 \\
LDL-choleserol $(\mathrm{mg} / \mathrm{dL})$ & $92.52 \pm 29.29$ & $91.61 \pm 65.57$ & 0.921 \\
\hline
\end{tabular}

TABLE 3 showed adipokines level in obese and non obese groups. Significantly higher in CRP and resistin levels in obese group compared to non obese group were observed $(\mathrm{p}<0.05)$. In contrast, no significantly different in TNF- $\alpha$ and IL-6 in both groups were reported.

TABLE 3. Level of CRP, TNF- $\alpha$, IL-6 and resistin (mean \pm SD) in obese and non obese subjects

\begin{tabular}{lccc}
\hline Variable & Obese & Non obese & $\mathrm{p}$ \\
\hline $\mathrm{CRP}(\mathrm{mg} / \mathrm{L})$ & $1.543 \pm 0.976$ & $1.044 \pm 0.256$ & 0.000 \\
$\mathrm{TNF}-\alpha(\mathrm{pg} / \mathrm{mL})$ & $58.32 \pm 97.52$ & $59.43 \pm 53.52$ & 0.939 \\
$\mathrm{IL}-6(\mathrm{pg} / \mathrm{mL})$ & $6.19 \pm 8.59$ & $8.75 \pm 7.77$ & 0.089 \\
Resistin $(\mathrm{pg} / \mathrm{mL})$ & $1,552.6 \pm 306.3$ & $1,250.0 \pm 288.9$ & 0.000 \\
\hline
\end{tabular}

\section{DISCUSSION}

Obesity is associated with a low-grade inflammatory process in the white adipose tissue (WAT) that leads to increase of circulation of inflammatory markers such as IL-6, CRP, and TNF- $\alpha$. In this study (TABLE 2), significantly higher blood glucose, insulin, triglyceride levels and HOMA-IR value in the obese subjects compared with those in non obese subjects were found. In contrast, significantly lower HDL-cholesterol in the obese subjects compared with those in non obese subjects were found. In addition, significantly higher in CRP and resistin levels in the obese subjects compared with those in non obese subjects were also found (TABLE $3)$.

Increases of these inflammation markers are caused by two phases. In the first phase, the fat tissue of obese patients becomes resistant to insulin because of the effects of several adipokines. In the second stage, this resistance occurs in other tissues and leads to increased levels of glucose and insulin. This increasing, together with increased levels of adipokines as clinical conditions due to obesity increase 
oxidative stress, endothelial dysfunction, blood pressure and disorders of lipoprotein metabolism, all of which are harmful to health. ${ }^{10}$ Inflammation of the WAT is due to obesity because macrophage infiltration is caused by the development of tissue mass. ${ }^{12,13}$

Other pathways of increasing levels of adipokines occur in response to hypoxia, because the mass of WAT expands in obesity, and as a result, the adipocytes become further from the blood vessels causing a relative lack of oxygen. Hypoxia then causes the stimulation of production and release of inflammatory cytokines, chemokines and angiogenic factors to stimulate blood flow and improve vascularization. ${ }^{14}$ Adipokine secretion is activated by extracellular and intracellular stress. Among the extracellular factors, free fatty acid (FFA) is a primary inductor of these pathways ${ }^{15,16}$ and in the obese, chronically FFA increases. Innate immunity receptors, such as toll-like receptor- 4 and -2 (TLR-4 and -2), expressed in WAT (mainly by adipocytes, preadipocytes, macrophages and endothelial cells) are involved in the inflammatory process associated with obesity. FFA and other molecules produced by hypoxic conditions during obesity activate these receptors, particularly TLR4. ${ }^{17,18}$ FFA also activate macrophages, especially CD11c+, through TLR-4, exacerbating proinflammatory activity. ${ }^{19,20}$

The CRP levels in obese group in this study was significantly higher than that in non obese groups. This result is consistent with other previous research findings. CRP levels were associated with decreased levels of HDL-cholesterol and insulin resistance, and increased BMI, waist circumference, blood pressure, triglyceride, blood glucose, insulin, HOMA- $\beta$. In addition, HOMA-IR showed a significant correlation between CRP levels and metabolic syndrome, including adiposity, hyperinsulinemia and insulin resistance., ${ }^{4,21,22}$ Recent research shows that there is a strong correlation between fasting insulin with CRP levels. ${ }^{23}$ In women, the increase of CRP levels are correlated with the increase of fat mass. ${ }^{24}$

In this study, significantly higher resistin levels in the obese group compared with that non obese group were found. Miyamoto et $a l .{ }^{25}$ reported that subjects with premature atherosclerosis have higher plasma resistin levels compared with subjects with established atherosclerosis. In addition, increased resistin expressions were found in type $2 \mathrm{DM}$, insulin resistance and obesity. ${ }^{26,27}$ However, Norata et $a l .{ }^{28}$ failed to detect any change in resistin levels in atherosclerotic conditions. Resistin may increase the susceptibility of metabolic syndrome by regulating adiponectin secretion from adipocytes and enhancing hepatic gluconeogenesis by inhibiting the enzymes involved in gluconeogenesis through AMPactivated protein kinase activation. ${ }^{29}$

In this study, no significantly different in the IL- 6 and TGF- $\alpha$ levels in obese group compared with those in non obese group were found. This result is similar with other previous study. ${ }^{30}$ Although IL-6 appears to be increasing in obesity and decreased in response to weight loss, our results showed no significantly different at baseline or in response to diet. Subcutaneous adipose tissue is estimated to release about $30 \%$ more IL-6 in systemic and visceral adipose tissue. However, small changes of IL-6 level in obese subjects show the levels of IL- 6 in obesity only about $10 \%$ of total IL- 6 that is produced by fat cells. ${ }^{31}$

Some reports indicated that in metabolic syndrome patients, the IL- 6 levels increased with BMI, however its mechanism is still unclear. In this study, the TNF- $\alpha$ levels were not significantly associated with body weight, waist circumference, or percentage of body 
fat at baseline. These results are in contrast to previous study showing the TNF- $\alpha$ level were associated with obesity. ${ }^{32}$ In addition, TNF- $\alpha$ levels did not show a significantly decline in response to weight loss or diet. They were not significantly different after the weight loss of $7.5 \%$ at 10 weeks. It is indicated that adipose tissue has only a small effect on the regulation of TNF- $\alpha$ levels. Furthermore, it is reported that TNF- $\alpha$ appears to act locally in human fat tissue $\mathrm{e}^{33}$ and it is not secreted from adipose tissue into the blood. Previous study indicated changes in IL- 6 or TNF- $\alpha$ after weight loss $(5-9 \mathrm{~kg})$ with dietary intervention and exercise. ${ }^{34}$ Changes in IL- 6 and TNF- $\alpha$ were significantly correlated with a weight loss diet for nine months in the group with low calorie diet. ${ }^{30}$ This result may explain the relationship between IL- 6 and TNF- $\alpha$ in which IL-6 provides proinflammatory activity and increases the TNF- $\alpha$ levels. This possibility shows that although the weight loss did not improve the IL- 6 and TNF- $\alpha$ in the circulation, there appears to be a significant clinical response demonstrating weight loss gives a reduction in inflammation. High levels of TNF- $\alpha$ are also seen in metabolic syndrome patients. ${ }^{35}$ The relationship between high levels of TNF- $\alpha$ and metabolic syndrome is associated with TNF-inducing NH2-terminal kinase c-jun to mediate phosphorylation of IRS-1 serine. This relationship determines the normal inhibition of tyrosine phosphorylation of IRS-1 and insulin signaling. ${ }^{36}$

\section{CONCLUSION}

In conclusion, the CRP and resistin levels as well as insulin resistance are higher in obese Javanese population compared to those non obese. Further genotype study to identify hereditary factors that may contribute to insulin sensitivity and resistance are recommended.

\section{ACKNOWLEDGEMENTS}

This study was supported by Ministry of Research and Technology and High Education, Republic of Indonesia through Excellent Higher Education Institution Research grant with contract number 632/UN11-PIII/DITIT/2016. Authors would like to thank all subjects who participated in this study.

\section{REFERENCES}

1. Ministry of Health, Republic of Indonesia. Indonesia Health Profile 2013. Jakarta : Ministry of Health, Republic of Indonesia, 2014.

2. de Luis DA, Aller R, Izaola O, Sagrado MRG, de la Fuente CB, and Ovalle HF, Allelic frequency of G380A polymorphism of tumor necrosis factor alpha gene and relation with cardiovascular risk factors and adipocytokines in obese patients. Nutr Hosp 2011; 26(4):7115.

3. Rajarajeswari D, Ramalingam K, Naidu $\mathrm{JN}$. Tumor necrosis factor-alpha in the development of lnsulin resistance in type 2 diabetes mellitus. Intern J Appli Biol Pharmaceut Tech 2011; 2(1): 55 - 60.

4. Al-Hamodi Z, AL-Habori M, Al-Meeri A, Saif-Ali R, Association of adipokines, leptin/ adiponectin ratio and $\mathrm{C}$-reactive protein with obesity and type 2 diabetes mellitus. Diabetol Metabolic Syndr 2014; 6(99): doi: 10.1186/1758-5996-6-99

5. Rodríguez-Rodríguez E, Perea JM, LópezSobaler AM, Ortega RM. Obesity, insulin resistance and increase in adipokines levels: importance of the diet and physical activity. Nutr Hosp 2009; 24(4):415-21.

6. Nakamura K, Fuster JJ, Walsh K. Adipokines: A link between obesity and cardiovascular disease. J Cardiol 2014; 63(4): 250-9. https://doi.org/10.1016/j.jjcc.2013.11.006 
7. Duman BS, Cagatay P, Hatemi H, Ozturk M, Association of resistin gene 3'-untranslated region $\mathrm{EX} 4-44 \mathrm{G} \rightarrow \mathrm{A}$ polymorphism with obesity- and insulin- related phenotypes in Turkish type 2 diabetes patients. Rev Diabet Stud 2007; 4(1):49-55. doi: 10.1900/ RDS.2007.4.49

8. Rajarajeswari D, Ramalingam K, Naidu $\mathrm{JN}$. Tumor necrosis factor-alpha in the development of insulin resistance in type 2 diabetes mellitus. Intern J Appli Biol Pharmaceut Tech 2011; 2(1): 55 - 60.

9. Teixeira AA, Quinto BMR, Dalboni MA, Rodrigues CJO and Batista MC. Association of IL-6 polymorphism -174G/C and metabolic syndrome in hypertensive patients. Bio Med Res Intern 2015; Article ID 927589, 6 pages

10. Wongwananuruk $T$, Rattanachaiyanont $M$, Leerasiri P, Indhavivadhana S, Techatraisak $\mathrm{K}$, Angsuwathana $\mathrm{S}$, et al. The usefulness of homeostatic measurement AssessmentInsulin Resistance (HOMA-IR) for detection of glucose intolerance in Thai women of reproductive age with polycystic ovary syndrome. Intern J Endocrinol 2012; Article ID 571035, 6 pages

11. Trayhurn P, Bing C, and Wood IS. Adipose tissue and adipokines - energy regulation from the human perspective. J Nutr 2006; 136(7): 1935S-9S.

12. Weisberg SP, McCann D, Desai M, Rosenbaum M, Leibel RL, Ferrante AW Jr. Obesity is associated with macrophage accumulation in adipose tissue. $\mathrm{J}$ Clin Invest 2003; 112:1796-808. https://doi.org/10.1172/JCI200319246

13. Xu H, Barnes GT, Yang Q, Tan G, Yang D, Chou CJ, et al. Chronic inflammation in fat plays a crucial role in the development of obesity-related insulin resistance. J Clin Invest 2003; 112:1821-30 https://doi.org/10.1172/JCI200319451
14. Trayhurn P, Wood IS. Adipokines: inflammation and the pleiotropic role of white adipose tissue. Br J Nutr 2004; 92:347-55 https://doi.org/10.1079/BJN20041213

15. Cnop M, Fatty acids and glucolipotoxicity in the pathogenesis of type 2 diabetes, Biochem Soc Transact 2008; 36(3): 348-52. https://doi.org/10.1042/BST0360348

16. Balistreri CR, Caruso C, and Candore G. The role of adipose tissue and adipokines in obesity-related inflammatory diseases. Mediator Inflamm 2010; Article ID 802078,

17. Ghanim H, Mohanty P, Deopurkar R, Sia CL, Korzeniewski K, Abuaysheh S. Acute modulation of Toll-like receptors by insulin. Diabetes Care 2008; 31(9): 1827-31. https://doi.org/10.2337/dc08-0561

18. Vitseva OI, Tanriverdi K, Tchkonia TT, Kirkland JL, McDonnell ME, Apovian CM, et al. Inducible toll-like receptor and NF$\kappa \mathrm{B}$ regulatory pathway expression in human adipose tissue. Obesity 2008; 16 (5): 932-37. https://doi.org/10.1038/oby.2008.25

19. Shi H, Kokoeva MV, Inouye K, Tzameli I, Yin $\mathrm{H}$, and Flier JS. TLR4 links innate immunity and fatty acid-induced insulin resistance. J Clin Invest 2006; 116 (11): 3015-25. https://doi.org/10.1172/JCI28898

20. Nguyen MTA, Favelyukis S, Nguyen AK, Reichart D, Scott PA, Jenn A, et al. A subpopulation of macrophages infiltrates hypertrophic adipose tissue and is activated by free fatty acids via toll-like receptors 2 and 4 and JNK-dependent pathways. J Biol Chem 2007; 282(48):35279-92. https://doi.org/10.1074/jbc.M706762200

21. Temelkova-Kurktschiev T, Siegert G, Bergmann S, Henkel E, Koehler C, Jaross $\mathrm{W}$, et al. Subclinical inflammation is strongly related to insulin resistance but not to impaired insulin secretion in a high risk population for diabetes. Metabolism 2002; 51: 743-9. https://doi.org/10.1053/meta.2002.32804 
22. Chou HH, Hsu LA, Liu CJ, Teng MS, Wu $\mathrm{S}$, et al. Insulin resistance is associated with $\mathrm{C}$-reactive protein independent of abdominal obesity in nondiabetic Taiwanese. Metabolism 2010: 59 (6): 824-30.

https://doi.org/10.1016/j.metabol. 2009. 09. 030

23. Pradhan AD, Cook NR, Buring JE, Manson JE, Ridker PM. C-reactive protein is independently associated with fasting insulin in nondiabetic women. Arterioscler Thromb Vasc Biol 2003; 23: 650-65.

https://doi.org/10.1161/01.ATV.0000065636. $15310.9 \mathrm{C}$

24. Aguirre L, Napoli N, Waters D, Qualls C, Villareal DT, Armamento-Villareal R. Increasing adiposity is associated with higher adipokine levels and lower bone mineral density in obese older adults. J Clin Endocrinol Metab 2014; 99(9):3290-7.

https://doi.org/10.1210/jc.2013-3200

25. Miyamoto $\mathrm{Y}$, Morisaki $\mathrm{H}$, Kokubo $\mathrm{Y}$, Yamanaka I, Tomoike H, Okayama Y, et al. Resistin gene variations are associated with the metabolic syndrome in Japanese men. Obes Res Clin Pract 2009; 3: I-II. doi: 10.1016/j.orcp.2008.11.003.

https://doi.org/10.1016/j.orcp.2008.11.003

26. Galic S, Oakhill JS, Steinberg GR. Adipose tissue as an endocrine organ. Mol Cell Endocrinol 2010; 316:129-39. https://doi.org/10.1016/j.mce.2009.08.018

27. Zhang MH, Na B, Schiller NB, Whooley MA. Association of resistin with heart failure and mortality in patients with stable coronary heart disease: data from the heart and soul study. J Card Fail 2011; 17(1):24-30. doi: 10.1016/j.cardfail.2010.08.007.

https://doi.org/10.1016/j.cardfail.2010.08.007

28. Norata GD, Ongari M, Garlaschelli K, Raselli S, Grigore L, Catapalo AL. Plasma resistin levels correlate with determinants of the metabolic syndrome. Eur J Endocrinol 2007; 156(2):279-84.

https://doi.org/10.1530/eje.1.02338
29. Weisberg SP, McCann D, Desai M, Rosenbaum M, Leibel RL, Ferrante Jr AW. Obesity is associated with macrophage accumulation in adipose tissue. J Clin Invest 2003; 112(12):1796-808. https://doi.org/10.1172/JCI200319246

30. Mitchell M, Armstrong DT, Robker RL, Norman RJ. Adipokines: implications for female fertility and obesity. Reproduction 2005; 130: 583-97. https://doi.org/10.1530/rep.1.00521

31. Rolland C, Hession M, Broom I. Effect of weight loss on adipokine levels in obese patients. Diabetes Metab Syndr Obes 2011; 4: 315-23. https://doi.org/10.2147/DMSO.S22788

32. Arvidsson E, Viguerie N, Andersson I, Verdich C, Langin D, Arner P. Effects of different hypocaloric diets on protein secretion from adipose tissue of obese women. Diabetes 2004; 53(8):1966-71.

https://doi.org/10.2337/diabetes.53.8.1966

33. Löfgren $P$, van Harmelen V, Reynisdottir $S$, Näslund E, Rydén M, Rössner S, et al. Secretion of tumor necrosis factor-alpha shows a strong relationship to insulinstimulated glucose transport in human adipose tissue. Diabetes 2000; 49(5):688-92. https://doi.org/10.2337/diabetes.49.5.688

34. Dvoráková-Lorenzová A, Suchánek P, Havel PJ, Stávek P, Karasová L, Valenta Z, et al. The decrease in $\mathrm{C}$-reactive protein concentration after diet and physical activity induced weight reduction is associated with changes in plasma lipids, but not interleukin-6 or adiponectin. Metabolism 2006; 55(3):359-65. https://doi.org/10.1016/j.metabol. 2005. 09. 010

35. Hotamisligil GS. Inflammation and metabolic disorders. Nature 2006; 444 (7121): 860-7. https://doi.org/10.1038/nature05485

36. Sabio G, Das M, Mora A, Zhang Z, Jun JY, Ko HJ, et al. A stress signaling pathway in adipose tissue regulates hepatic insulin resistance. Science 2008; 322(5907): 1539 43.

https://doi.org/10.1126/science.1160794 